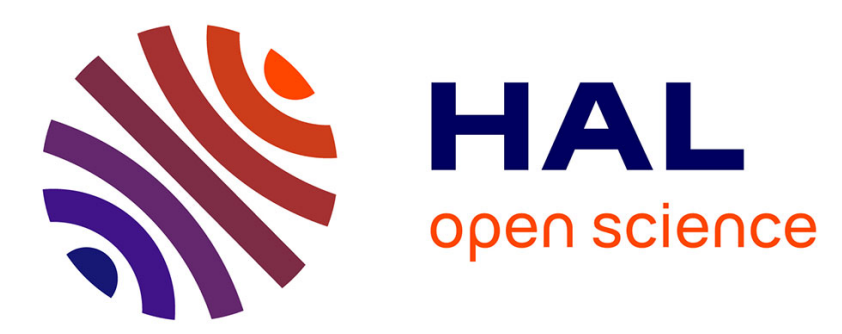

\title{
New Italian directional and intensity archaeomagnetic reference curves for the past 3000 years: Insights on secular variation and implications on dating \\ E. Tema, P. Lanos
}

\section{- To cite this version:}

E. Tema, P. Lanos. New Italian directional and intensity archaeomagnetic reference curves for the past 3000 years: Insights on secular variation and implications on dating. Archaeometry, 2021, 63 (2), pp.428-445. 10.1111/arcm.12603 . halshs-03512464

\section{HAL Id: halshs-03512464 \\ https://shs.hal.science/halshs-03512464}

Submitted on 5 Jan 2022

HAL is a multi-disciplinary open access archive for the deposit and dissemination of scientific research documents, whether they are published or not. The documents may come from teaching and research institutions in France or abroad, or from public or private research centers.
L'archive ouverte pluridisciplinaire HAL, est destinée au dépôt et à la diffusion de documents scientifiques de niveau recherche, publiés ou non, émanant des établissements d'enseignement et de recherche français ou étrangers, des laboratoires publics ou privés. 


\title{
NEW ITALIAN DIRECTIONAL AND INTENSITY ARCHAEOMAGNETIC REFERENCE CURVES FOR THE PAST 3000 YEARS: INSIGHTS ON SECULAR VARIATION AND IMPLICATIONS ON DATING*
}

\author{
E. TEMA \\ Dipartimento di Scienze della Terra, Università degli Studi di Torino, via Valperga Caluso, 35, \\ Turin, I 10125, Italy and ALP Alpine Laboratory of Palaeomagnetism, via Luigi Massa, 6, \\ Peveragno, I 12016, Italy \\ P. LANOS \\ CNRS IRAMAT CRP2A, Université Bordeaux Montaigne and Géosciences Rennes, Université Rennes 1, \\ France
}

\begin{abstract}
We present the first Italian reference secular variation curves for both direction and

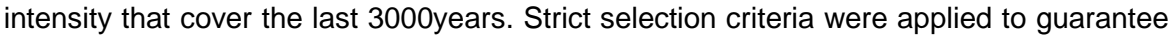
the collection of the most reliable data within a $1000 \mathrm{~km}$ radius of Viterbo, including archaeomagnetic re-cords from archaeological material and volcanic rocks. The new curves are calculated using Bayesian statistics and they depict interesting geomagnetic field features, such as high intensity periods. These are the first curves for Italy, including both directional and intensity data, and they can be used as reference curves for archaeomagnetic dating, not only in Italy but also in nearby countries.
\end{abstract}

KEYWORDS: SECULAR VARIATION, GEOMAGNETIC FIELD, ARCHAEOMAGNETIC DATING, ITALY, EUROPE

\section{INTRODUCTION}

Understanding the behavior of the Earth's magnetic eld in the past is very important. On the one hand, it can offer insights into the processes that take place in the external core and contribute to the investigation of the origin and nature of the geomagnetic eld's behavior (e.g., Terra Nova et al. 2016). On the other hand, knowledge about the secular variation (SV) path in ancient times can be used as a dating tool to determine the age of archaeological material (e.g., Tema et al. 2014) and volcanic rocks of unknown age (e.g., Böhnel et al. 2016). As the Earth's magnetic eld is continuously changing in both time and space, the investigation of its past SV can be made at local or regional scales through the establishment of reference SV curves for those areas where enough well dated archaeomagnetic data are available. In the case of Europe, having the greatest density of reference geomagnetic eld data, several SV curves have been proposed thus far (e.g., Tema and Kondopoulou 2011; Kovacheva et al. 2014; Batt et al. 2017; Molina Cardín et al. 2018).

Italy has a very rich and long cultural heritage and important volcanic activity due to the long eruptive history of the country's two principal active Italian volcanoes, Vesuvius and Etna. 
Despite this high potential, no full geomagnetic eld vector reference curve is available so far. Tema et al. (2006) proposed a first directional SV curve based on 65 archaeomagnetic results ranging in time from $1300 \mathrm{BCE}$ to $1700 \mathrm{CE}$. This preliminary curve was mainly based on data obtained from archaeological sites, while only a few directions from volcanic eruptions were considered. Malfatti et al. (2009) also proposed a directional SV curve for Italy, for the period $1200 \mathrm{BCE}-100 \mathrm{CE}$, using archaeomagnetic data included in a $1200 \mathrm{~km}$ radius around Naples.

Regarding the intensity variation of the Earth's magnetic eld in Italy, no continuous reference curve covering the last millennia is thus available. Tema (2011) compiled the first systematic catalogue of Italian archaeointensity data, presenting 23 intensity records ranging from $800 \mathrm{BCE}$ to 1960 CE. A few years later, Tema et al. (2013a) attempted to calculate an intensity SV curve for the Italian peninsula using archaeointensity data from Italy and nearby countries within a $900 \mathrm{~km}$ radius of Viterbo. However, the very limited number of reference data has not allowed the construction of a continuous SV curve and only fragments of a reference curve were proposed for the 300 BCE-400 CE and 1200-1900 CE periods. More recently, Genevey et al. (2019) published 14 new archaeointensity data from bricks collected from historical buildings around Pisa, with ages ranging from the 12th to the 17th centuries CE. These new Tuscany results together with selected data within a $700 \mathrm{~km}$ radius of Beaune (France) were used to calculate an intensity SV curve for Western Europe covering the period 900-1900 CE (Genevey et al. 2019)

In this paper we propose a revised collection of Italian archaeomagnetic data, including archaeomagnetic records from archaeological structures, displaced artefacts and volcanic rocks. Strict selection criteria were applied, particularly focusing on the dating of the volcanic rocks and on the quality of the archaeointensity data. The first Italian reference SV curves for both direction and intensity are proposed, based on a selection of data included in a $1000 \mathrm{~km}$ radius of Viterbo. The new curves offer insights into the evolution of the Earth's magnetic eld in the central Mediterranean and can be used as reference curves for archaeomagnetic dating applications in Italy and nearby countries.

\section{ARCHAEOMAGNETIC DATA}

\section{Volcanic rocks}

In Italy, volcanic rocks have been widely used for palaeomagnetic investigations (e.g., Rolph et al. 1987; Incoronato et al. 2002; Tanguy et al. 2003; Principe et al. 2004; Speranza et al. 2006; Tanguy et al. 2007). The strong and stable thermoremanent magnetization (TRM) ac-quired during the cooling of the volcanic products makes them a precious source of information for tracing the path of the geomagnetic eld SV. However, at the same time, the use of TRM directions from volcanic rocks requires a certain caution, as often problems related to their sampling, dating and the strongly magnetized volcanic edifice may be important. Lanza et al. (2005) compared the remanence directions derived from historically dated volcanic rocks from Etna and Vesuvius with direct measurements of the Earth's magnetic eld available since 1640 $\mathrm{CE}$, showing that the great majority of the best defined directions $\left(\alpha_{95}<2.5^{\circ}\right)$ deviate significantly from the corresponding geomagnetic direction. Pavón Carrasco et al. (2016) further explored this dispersion by comparing directional volcanic and archaeomagnetic data for the last four centuries with the predictions of the historical GUFM1 model (Jackson et al. 2000), observing a systematic inclination shallowing effect in the Italian volcanic data set. Speranza et al. (2006) used historical lavas from Etna to investigate the reliability of paleomagnetic dating 

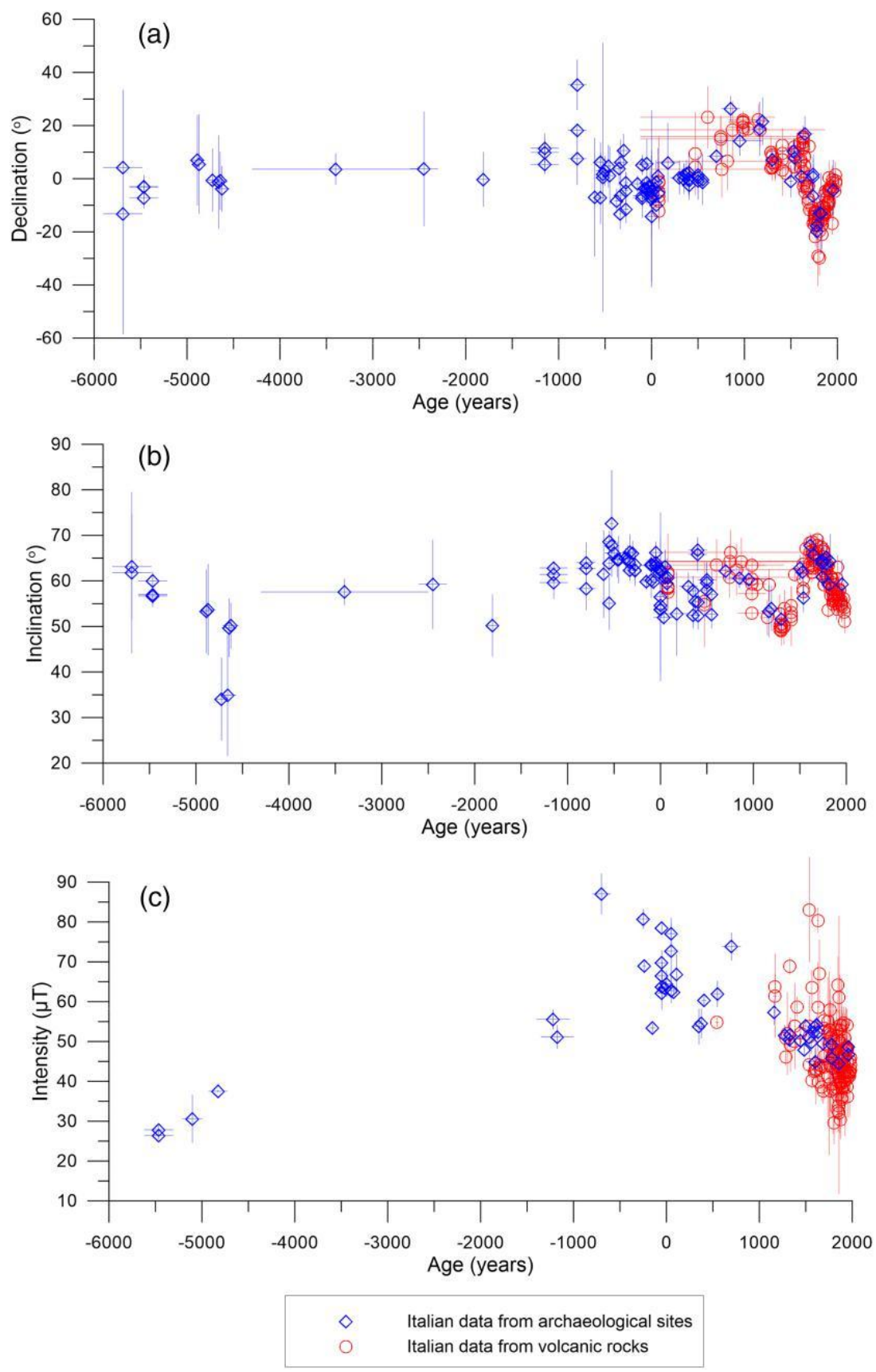

Figure 1 Plots of the Italian archaeomagnetic data (a) declination, (b) inclination and (c) intensity from volcanic rocks (red circles) and archaeomagnetic material (blue diamonds) for the last 8000 years 
of volcanic products, concluding that the strong magnetization of both the underlying terrain and the cooling ow itself may cause the scatter of the obtained directions.

However, probably the most important source of error concerning archaeomagnetic data from Italian volcanoes remains their precise age. In some cases, precise dating is available thanks to the abundance of detailed historical documents, as, for example, for the eruption in 79 CE of Vesuvius. Nevertheless, that is not always the case. Even when the age of an eruption is known, it is still difficult to be sure that the volcanic products collected in the eld correspond to that specific eruption. There are several cases where the historically attributed age of Italian volcanic rocks has been contested. Tanguy et al. (2007) revised the chronology of many volcanic rocks emplaced during the last 2750 years at Etna, showing that despite the abundance of historical in-formation on the ancient eruptions dates, the primary sources of information are often too imprecise to identify the corresponding lava flows and the related eruptive systems. They concluded that the ages of most of the eruptions before $1700 \mathrm{CE}$ published in geological maps may in fact be hundreds of years older.

In this study, an updated data set of the available Italian volcanic data was compiled, with a particular focus on the reliability of their historical dating. The data were collected from the original publications and global databases (Brown et al. 2015; Arneitz et al. 2017). A total of 231 directional and 137 intensity data are available, all concentrated in the last two millennia. Data from older periods are poorly dated or the dating errors are extremely large.

Most of the palaeomagnetic data come from the historical eruptions of Etna and Vesuvius, while some data also come from the Aeolian Islands and the 1301 CE eruption of Ischia. Impressively, the $85 \%$ of the intensity data come from volcanic rocks emplaced during the last four centuries, mainly from studies that use such recent historic lava flows to test the reliability of the archaeointensity determinations (e.g., Hill and Shaw 1999; Calvo et al. 2002). To guarantee the reliability of the dating of the available Italian volcanic reference data, we controlled the original publications, paying attention to evidence of debates or doubts about their historical age. Such revision shows that only $57 \%$ of the volcanic palaeomagnetic records come from well dated eruptions. For the rest of the data, the traditional age of the eruption was questioned and/or changed based on geological evidence and/or archaeomagnetic dating. Such eruptions, whose historical age was in doubt or archaeomagnetically corrected, were excluded here from further considerations.

\section{Archaeological material}

The most updated catalogue of Italian archaeomagnetic data is provided by Tema (2011), who lists a total of 73 directions ranging from $5900 \mathrm{BCE}$ to $1612 \mathrm{CE}$, and 23 intensities from 800 BCE to 1960 CE. More recently new archaeomagnetic studies (e.g., Malfatti et al. 2011; Tema et al. 2013a, 2013b, 2014, 2015, 2016; Kapper et al. 2014, 2015; Genevey et al. 2019) enriched the Italian archaeomagnetic data set to a total of 103 directions and 49 intensities. In the great majority, the archaeomagnetic directions come from kilns, ovens and small hearths, while some of the data come from the study of mural paintings and in situ red walls. It is interesting to note that even the intensity data mostly come from kilns or architectural bricks rather than from pottery sherds.

A comparison between the available archaeomagnetic directions from archaeological material and volcanic rocks of undisputable age shows very good agreement (Fig. 1, a, b). The intensity data are also in agreement (Fig. 1, c), but it is worth noting that the intensities from volcanic rocks show an important dispersion even during recent times (the last few centuries). Both directional and intensity data are mainly concentrated in the last three millennia, whilst only a few data for older periods (before $1000 \mathrm{BCE}$ ) exist.

\section{Reference data and selection criteria}

The quality of the reference data is very important for the construction of a detailed and reliable SV curve, aiming to identify the ne characteristics of the geomagnetic field behaviour in the past. For this reason, several quality criteria have been used in the literature (Tema and Kondopoulou 
2011; Hervé et al. 2013; Batt et al. 2017; Tema et al. 2017). Most are based on the age uncertainties of the studied materials and laboratory measurements errors. However, even if such selection criteria are important, they are not always sufficient. Lanza et al. (2005) showed that even when very small $\alpha_{95}$ angles of confidence $\left(<2.5^{\circ}\right)$ are obtained, they cannot guarantee the reliable record of the true ancient eld direction. Tanguy et al. (2007), as previously discussed, showed that even the very well defined directions of volcanic rocks from Etna may not be reliable reference data as they are accompanied by erroneous historical dates. Unfortunately, such problems cannot be easily recognized, and such data are generally used for the computation of geomagnetic eld models, passing the traditional selection criteria.

Pavón Carrasco et al. (2014) investigated the influence of the quality of the intensity data on geomagnetic eld modelling. They divided the European archaeointensity data set into four quality categories based on the number of specimens and laboratory protocols applied. Their study shows that models obtained after preselection, considering only the high quality data, are more accurate than those based on all the available data (without any selection), even if the number of reference data in the second case is significantly larger. In the category of the most reliable data, they included only archaeointensity data that come from at least five specimens and obtained from the original Thellier or modified method, including partial thermoremanent magnetization (pTRM) checks and anisotropy correction. Particular attention to the archaeo intensity protocol used is also given in other recent studies (e.g., Molina Cardín et al. 2018).

According to these results, we have applied strict quality criteria to select the most reliable data available from both archaeological material and volcanic rocks. Our compilation was limited to the last 3000 years, as data from older periods are unfortunately extremely few. Undoubtedly, choosing the most appropriate selection criteria is not an easy task and the criteria proposed in the literature are numerous. It is hard to say which cut off value is the best choice and if numerical criteria are enough to guarantee the rejection of unreliable records. In this study we followed the quality criteria proposed by Pavón Carrasco et al. (2014), corresponding to category A (characterized as the most reliable data), as it was shown that they give the most accurate SV reconstructions. Our reference data set was thus selected according: (1) the number of specimens being five or more; (2) $\alpha_{95} \leq 5^{\circ}$ for directional data and $\sigma \leq 5 \mathrm{~T}$ for intensity studies; (3) age errors 200years; and (4) for the intensity data, they should be obtained by Thellier type methods, multi specimen and/or the Triaxe technique, including anisotropy and cooling rate corrections when necessary. Particularly attention was focused on the reliability of the dating of volcanic rocks by controlling the original publications to check for doubts or a reevaluation of their historical age. Only volcanic rocks with undisputable age were considered (eruptions whose historical age was in doubt or archaeomagnetically corrected were not taken into consideration). All data with missing metadata information were also rejected. Even though these may be considered as relatively 'strict' selection criteria, we believe that in this way they can at least guarantee the rejection of the less precise data allowing the identification of geomagnetic eld features that otherwise could be hidden by the data's dispersion. The selected Italian archaeomagnetic data set that fulled these criteria consisted of 170 directions and 29 intensities. Most of the intensity re-cords were rejected due to the low number of specimens and to the palaeointensity protocols used. It is interesting to note that from the 137 initial intensity data from volcanic rocks, only one record passed the applied selection criteria. The final selected Italian data set is reported in Table S1 in the additional supporting information.

To enhance the Italian data set and to cover those time periods that were poorly investigated in Italy, we also considered high quality archaeomagnetic data available from sites within a 1000 $\mathrm{km}$ radius of Viterbo $\left(42.45^{\circ} \mathrm{N}, 12.03^{\circ} \mathrm{E}\right)$. Viterbo is situated in central Italy, around $70 \mathrm{~km}$ north of Rome, and it was proposed as the most suitable reference site for Italy as it gives the smallest relocation error (Lanza and Zanella 2003). The radius of $1000 \mathrm{~km}$ was chosen as it can enrich the reference data set with new data from countries near Italy, but at the same time it guarantees a relative low relocation error for both directional and intensity data (Casas and Incoronato 2007). Data from the neighborhood countries were selected from global databases (Brown et al. 2015; Arneitz et al. 2017) following the same selection criteria applied to the Italian 
data set (see Table S2 in the additional supporting information). These data enrich the final archaeomagnetic database for the last three millennia with additional 424 directional and 65 intensity high quality records (Fig. 2).

The selected directional data were relocated to the coordinates of Viterbo using the virtual geomagnetic pole method, and the intensity data were reduced at the latitude of Viterbo via the virtual dipole moment. All data are plotted in Figure 3.

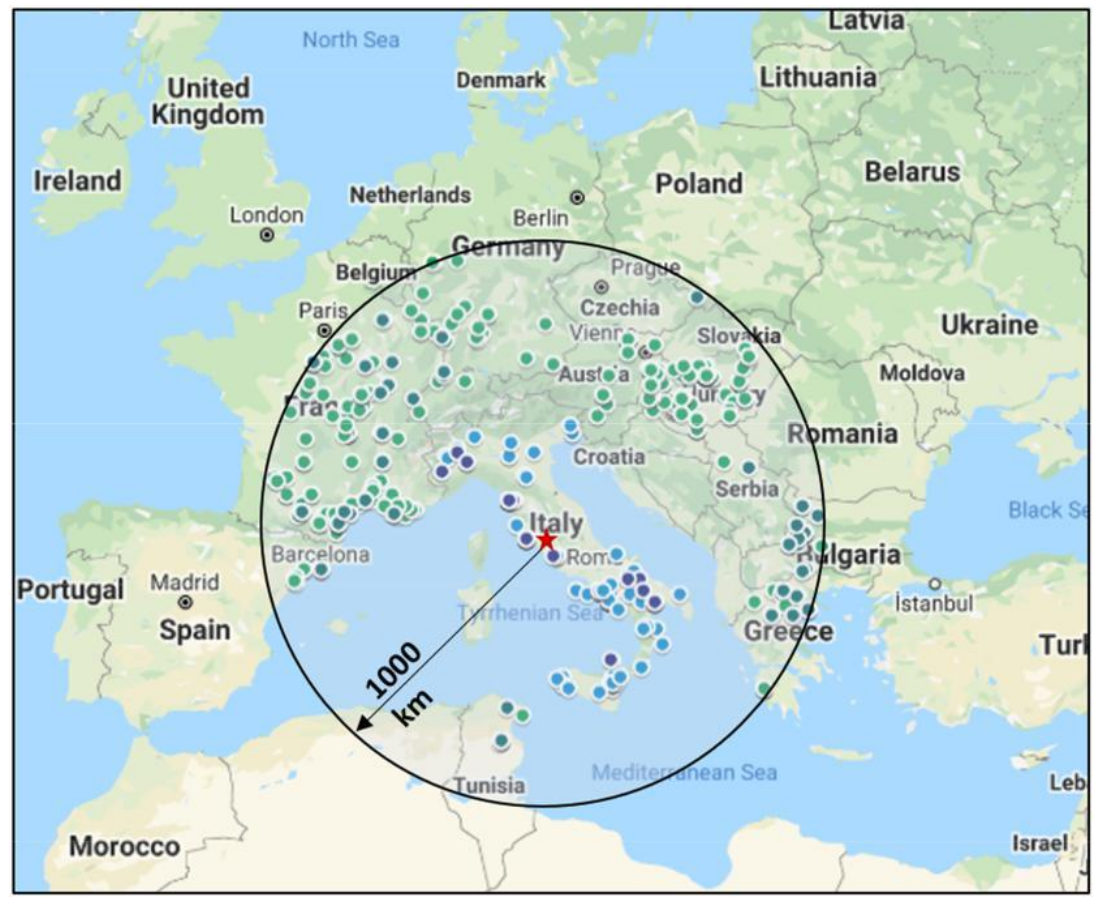

Figure 2 Geographical distribution of the selected (see the text) archaeomagnetic data from Italy and nearby countries within a $1000 \mathrm{~km}$ radius of Viterbo (red star): light blue dots, directional data from Italy; dark blue dots, intensity data from Italy; light green dots, directional data from nearby countries; and dark green dots, intensity data from nearby countries. 

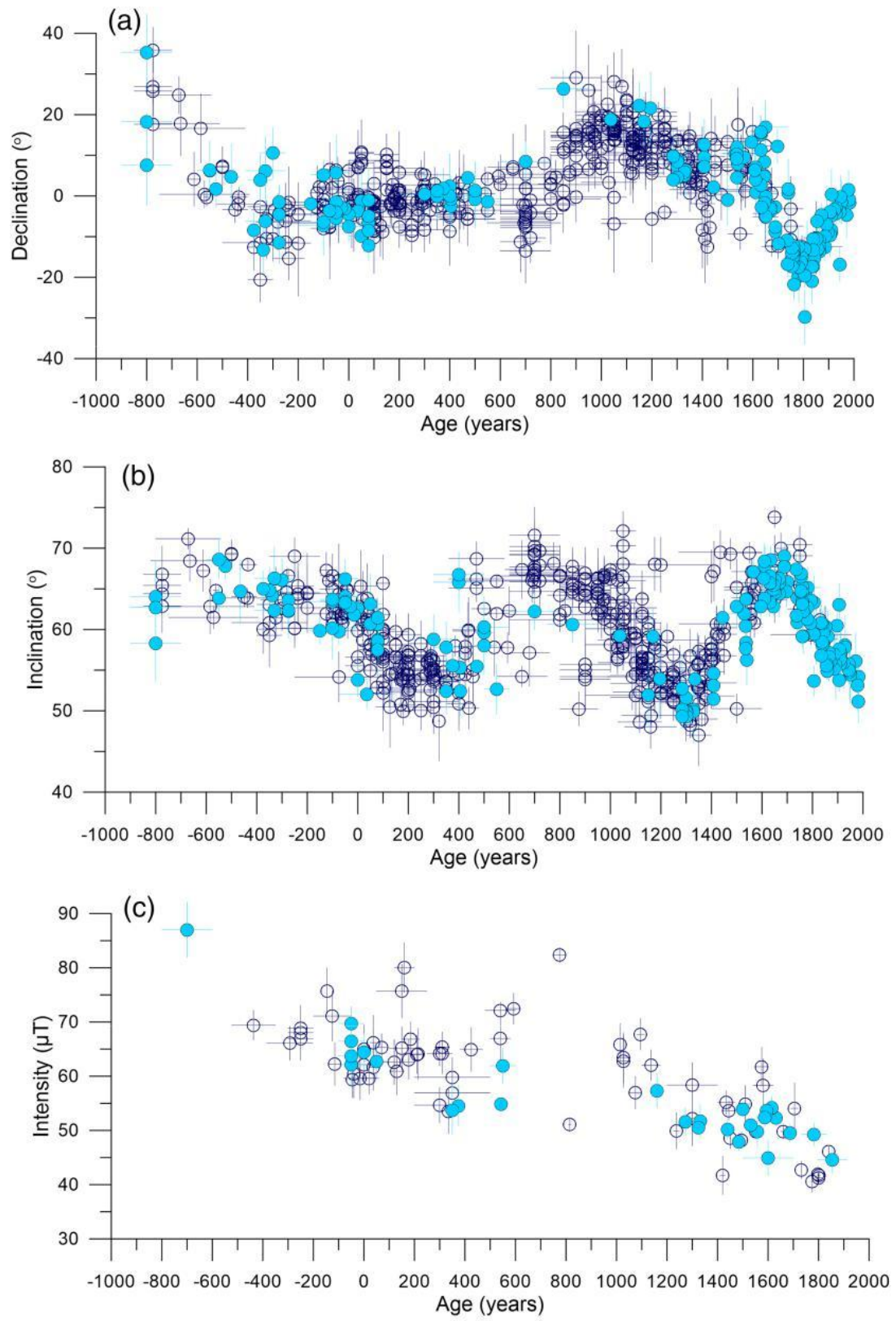

$$
\begin{aligned}
& \text { Italian archaeomagnetic data } \\
& \text { Data from nearby countries } \\
& \text { (within } 1000 \mathrm{~km} \text { radius from Viterbo) }
\end{aligned}
$$

Figure 3 Plots of the selected (a) declination, (b) inclination and (c) intensity data from Italy (light blue dots) and nearby countries (open dark blue dots). All data are relocated at Viterbo $\left(42.45^{\circ} \mathrm{N}, 12.03^{\circ} \mathrm{E}\right)$. 

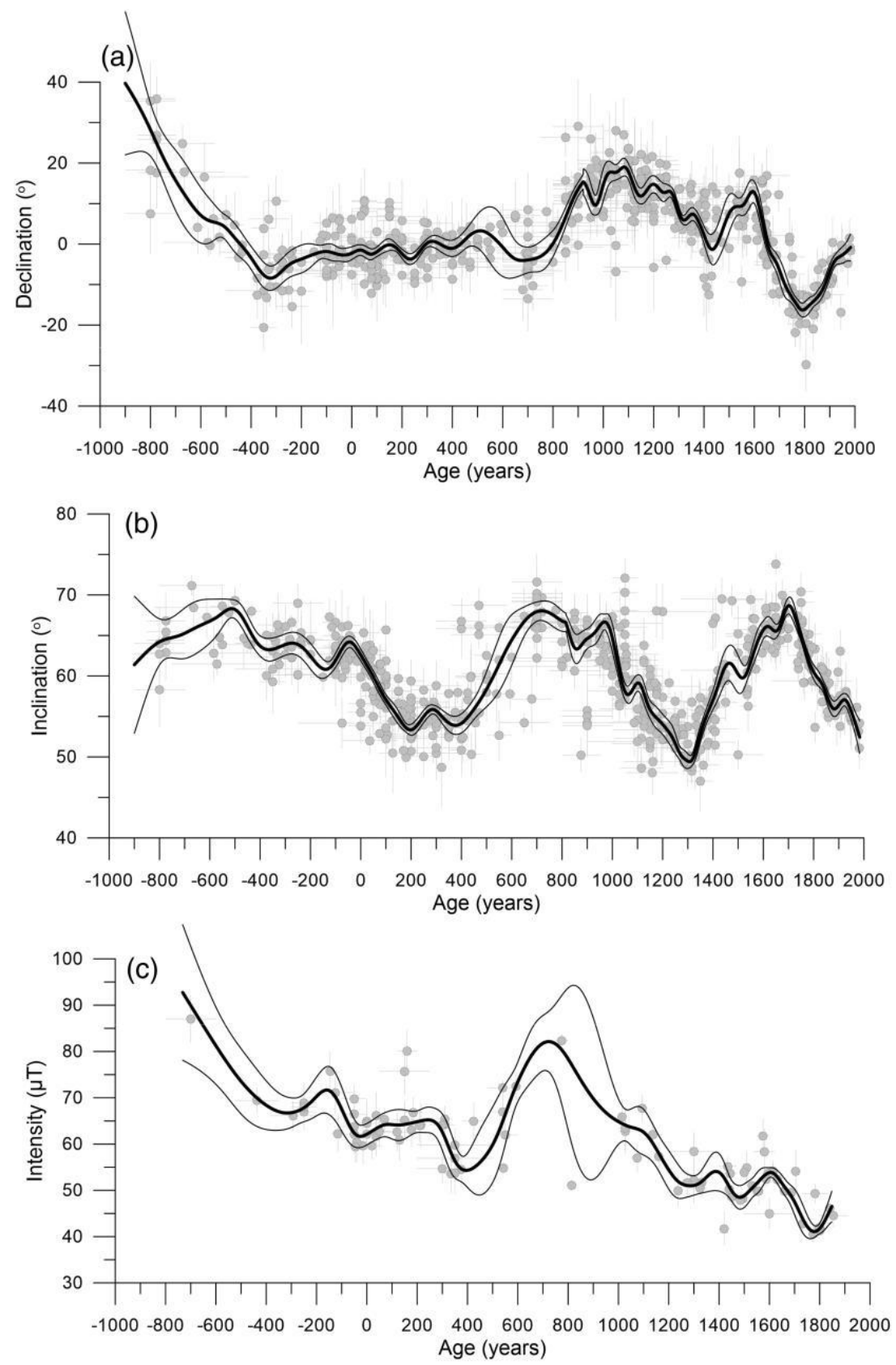

Reference archaeomagnetic data from Italy and nearby countries Italian SV curve accompagnied by $95 \%$ error envelope

Figure 4 New Italian secular variation curves for (a) declination, (b) inclination and (c) intensity plotted together with the reference data. The curves are calculated using Bayesian statistics and are accompanied by the $95 \%$ error envelop. 


\section{NEW SV REFERENCE CURVES FOR THE ITALIAN PENINSULA}

The new directional and intensity reference SV curves for the Italian peninsula were calculated based on a total of 594 directional and 94 intensity high quality reference data. The curves were obtained using Bayesian statistics for constructing chronologies (Lanos 2004), applying recent advances (Lanos and Philippe 2018; Lanos and Dufresne 2019). The applied algorithm uses prior information on the data (when available) and considers both experimental errors and age uncertainties that are translated into probability density functions. The updated version of the Bayesian algorithm used here is similar to that used for the calculation of the Hawaiian curves (Tema et al. 2017). It presents the advantage that over dispersions are a priori added to the measurements and to the dates in a hierarchical Bayesian framework in order to consider unknown errors that are not included in experimental and dating errors provided by the laboratory protocols and dating techniques, respectively (Lanos and Philippe 2018). A prior probability of the smoothing parameter is also applied to control the degree of the cubic spline function smoothing used for curve estimation, replacing the cross validation technique previously used (Lanos 2004). Consequently, this more comprehensive modelling provides an efficient automatic penalization of outliers and leads to a more adaptive curve estimate. In this study, most of the directional and intensity data come from different studies, so it was not possible to calculate a curve based on the modelling of the full geomagnetic eld vector. The directional curve $(D, I)$ was thus calculated using a spherical approach, while the intensity curve was computed separately. Each estimated curve was accompanied by an error envelope expressed at a $95 \%$ confidence level, defined by a variance deduced from the Monte Carlo Markov Chain (MCMC) calculation process. The calculated curves subsampled every 20years are provided in Table S3 in the additional supporting information.

The new curves were calculated at the geographical coordinates for Viterbo $\left(42.45^{\circ} \mathrm{N}\right.$, $12.03^{\circ} \mathrm{E}$ ), and plotted in Figure 4 together with the reference data. The directional curves are very well constrained for most of the last three millennia thanks to the large number of high quality reference data (Fig. 4, a, b). Only for the 900-500 BCE and 500-800 CE time intervals, the curves are accompanied by wider error envelopes, clearly due to the smaller number of reference data. The intensity curve, instead, is accompanied by a relatively wide error envelope for almost the whole time period studied (Fig. 4, c), due to the small number of available data and their higher dispersion with respect to the directional records. Some points around 200 and $800 \mathrm{CE}$ were identified as outliers by the calculation algorithm and were underweighted during the calculations. Note that there are only two intensity points between 600 and $1000 \mathrm{CE}$; the calculation preferred to pass through the highest intensity record following the trend indicated by the preceding and following data. Clearly, more intensity data are needed for this period. Nevertheless, the proposed curves can highlight efficiently some clear geomagnetic eld aspects and describe the geomagnetic eld variations during the last three millennia, not only in Italy but also in the central Mediterranean and in nearby to Italy countries such as southern France, southern Germany, Croatia, Serbia, Albania, etc.

\section{DISCUSSION}

\section{Secular variation path in the central Mediterranean}

The privileged geographical position of the Italian peninsula, situated almost in the center of the Mediterranean, offers the opportunity to use the new SV curves to analyze the evolution of the geomagnetic eld in Central Europe and to investigate the interesting characteristics of past eld behavior. For this reason, we compared the new curves with the available full vector SV curves for Western and Eastern Europe, such as the Iberian SV curves calculated at Madrid (Molina Cardín et al. 2018) and the Bulgarian SV curves calculated at Kazanlak (Kovacheva et al. 2014). 
The Iberian curves were obtained from a selection of high quality data from Spain, Portugal, France and Morocco using the hierarchical bootstrap method. The Bulgarian SV curves were calculated based on a very large data set of revised and re-evaluated Bulgarian data, elaborated with the Bayesian statistics for curve building.

A comparison of the directional curves generally shows a very good agreement (Fig. 5, a). The only important differences are at around 600-900 CE, when the lberian curve shows high declinations, while the Italian and Bulgarian curves show low declinations, and also around $1500-1600$ CE when the Italian curve shows a declination peak that is not observed in the Bulgarian curve. Regarding the inclination curves, some interesting observations can be made (Fig. 5, b). In both Italian and Iberian curves, low inclinations of around $53^{\circ}$ are observed around $200 \mathrm{CE}$, while the Bulgarian curve shows even lower inclinations, but around two centuries later, at $400 \mathrm{CE}$, in correspondence with a second small inclination low of the Italian curve. From 400 to $700 \mathrm{CE}$, the Italian inclination curve shows a continuous and fast inclination increase. For

(a)

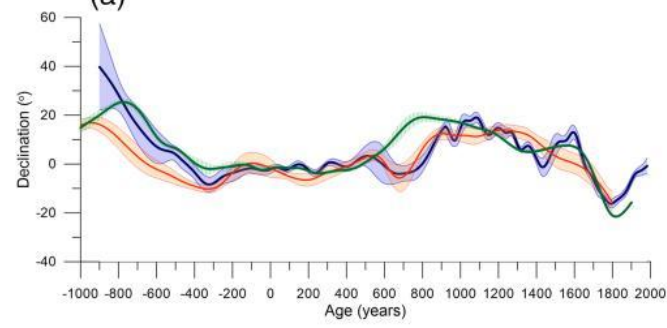

(b)
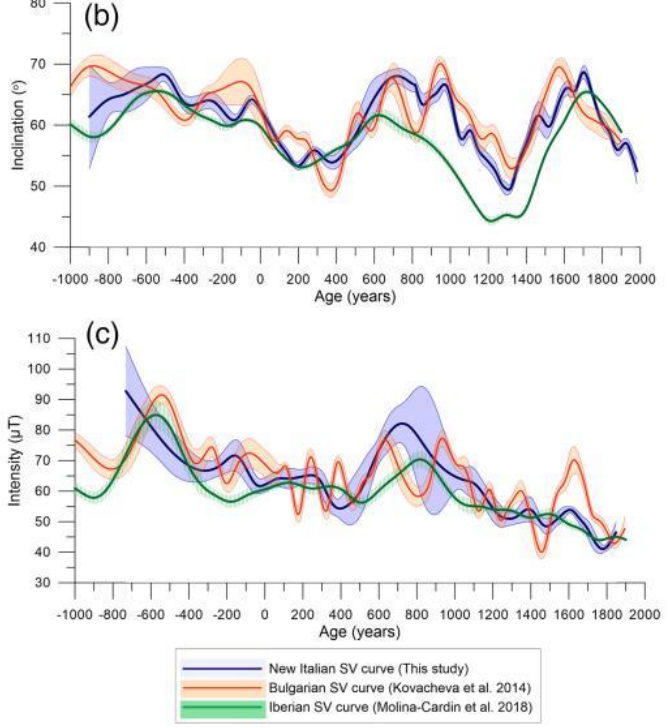

(d)

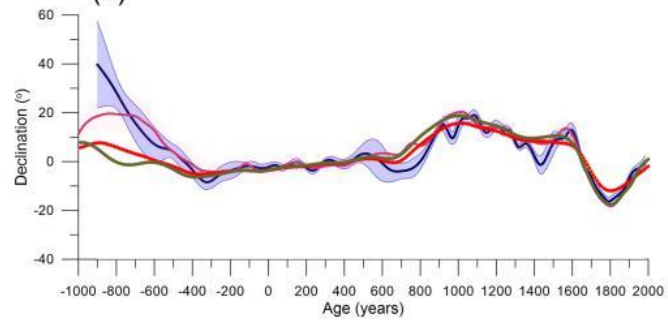

(e)

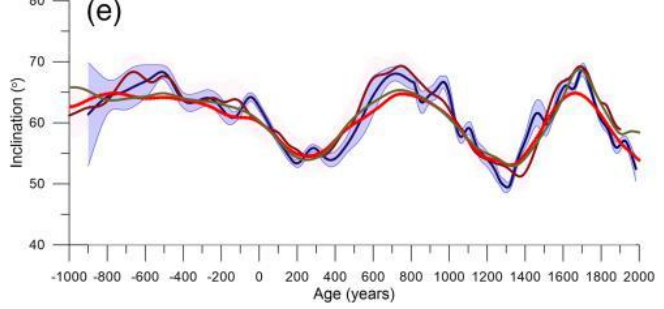

(f)

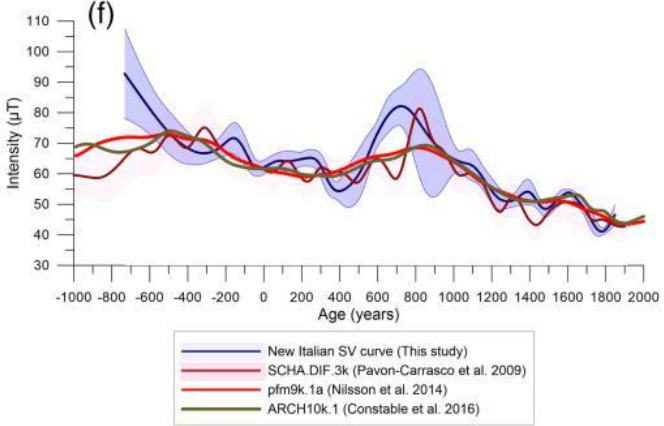

Figure 5 New Italian secular variation curves compared with the Bulgarian and lberian curves $(a-c)$ and with the pre-dictions of geomagnetic field models $(d-f)$. 
the same period, a continuous inclination increase is also observed in the lberian curve, even though it is less abrupt and characterized by lower values. A clear inclination low is seen in all curves around $1300 \mathrm{CE}$ and then a continuous increase up to high inclinations of around $70^{\circ}$, observed around $1600 \mathrm{CE}$ in the Bulgarian curve and around a century later, at $1700 \mathrm{CE}$, in the Italian and Iberian curves (Fig. 5, b).

A comparison of the intensity curves is also interesting, showing a general agreement, but some differences, too (Fig. 5, c). The Bulgarian curve exhibits many rapid variations, despite the use of the Bayesian algorithm similar to that applied here. Such short variations are not seen in either the Italian or the Iberian curves. This difference could be caused either by the different number of reference points used for the calculation of the various curves or by the different quality criteria applied for the selection of the data. The Bulgarian intensity SV curve was calculated based on 170 intensity records available for the last 3000 years, much more than the reference points used in the present study. The data set used was based on a re-evaluation of previously published Bulgarian results, but no clear quality selection criteria were applied (Kovacheva et al. 2014). On the other hand, the Iberian intensity SV curve was based on 115 intensity re-cords, selected according to quality criteria very similar to those applied here (Molina Cardín et al. 2018). Probably, applying strict selection criteria and using a similar number of reference data leads to the calculation of a more similar intensity variation path between Italy and Iberia (Fig. 5, c). Indeed, the general trend of the lberian curve is in very good agreement with the new Italian curve, with an exception around 200 BCE when the lberian curve shows low intensities while the Italian curve shows a small high intensity peak. Another difference is noticed around 700-800 CE when the Italian curve shows high intensities of around $85 \mathrm{~T}$, while the Iberian peak has values around $70 \mathrm{~T}$ (Fig. 5, c). However, it should be underlined that the Italian intensity curve for this period is based on only one high intensity record.

The new curves are also compared with the SCHA.DIF.3k regional model (Pavón Carrasco et al. 2009), and with the pfm9k.1a (Nilsson et al. 2014) and ARCH10k.1 (Constable et al. 2016) global geomagnetic eld models, calculated for the coordinates of Viterbo. Such a comparison shows in most cases a very good agreement (Fig. 5, d-f). All declination curves are very similar, confirming a continuous declination decrease from 900 to $400 \mathrm{BCE}$, and very small declination variations from $400 \mathrm{BCE}$ to $500 \mathrm{CE}$ with almost stable declinations towards the north. Then, from 600 to $1000 \mathrm{CE}$, the declination is almost continuously increasing. The Italian curve shows a clear declination low around $1400 \mathrm{CE}$, a declination peak around $1600 \mathrm{CE}$ and then a continuous decrease up to $1800 \mathrm{CE}$. Such variations are observed in the models, too, but in a smoother way. The Italian inclination curve is also in good agreement with the models, and particularly with the SCHA.DIF.3k model predictions (Fig. 5, e). More differences are observed in the intensity curves with the high intensity peak seen around $800 \mathrm{CE}$ in the SCHA.DIF.3k model, being observed slightly earlier in the Italian curve. Moreover, the Italian intensity curve shows high intensities of about $85 \mathrm{~T}$ around $800 \mathrm{BCE}$ that are not predicted in any of the published geomagnetic models, but they are however in good agreement with the intensity curves from Western Europe and southern Germany (Hervé et al. 2013, 2017). Undoubtedly, the differences on the reference data sets and the different mathematical approaches used for the calculation of the local SV curves and the global eld models could be the source of the discrepancies observed, keeping in mind that some models include sedimentary records in their reference data set and inevitably show a smoother variation (Nilsson et al. 2014).

Lastly, we used the new Italian SV curves to investigate the occurrence of eventual fast and abrupt directional and intensity geomagnetic eld variations in the area. During the last decades, many studies have shown that the geomagnetic eld has exhibited numerous intense, short lived, 
regional variations identified at different geographical locations. In France, several periods of rapid geomagnetic eld changes were identified, characterized by sharp changes in direction which coincide with intensity maxima, called archaeomagnetic jerks (e.g., Gallet et al. 2003). In other studies, very high eld intensities associated with rapid SV rates were observed, defined as geomagnetic intensity spikes. Such high intensities have been identified in several geographical areas, with most known the Levantine Iron Age Anomaly (LIAA) (Shaar et al. 2016, pas-sim). The exploration of their origin and geographical occurrence is particularly interesting (Korte and Constable 2018), but till now, the global geomagnetic eld models cannot clearly re-produce such rapid intensity variations, mainly due to the lack of many, worldwide homogeneous distributed, well dated and of high quality reference data that could depict these short lived changes. In such a perspective, the contribution of local databases and SV curves based on a strict selection of both directional and intensity data such as the ones presented here may be important. Indeed, the Italian SV curves clearly show a continuous decrease in declination and intensity from 800 to $300 \mathrm{BCE}$ and a well constrained increase in inclination and intensity from 400 to $800 \mathrm{CE}$. A very similar trend is also seen in Central Europe, based on recently published directional data from Germany and Austria (Schnepp et al. 2020). The very high intensity value of

85 T observed in Italy around $800-700$ BCE is in good agreement with the LIAA high intensity reported in Israel at the beginning of the eighth century BCE (Shaar et al. 2016), but as it is based on only one reliable record, more data are still necessary to con $\mathrm{rm}$ it further. However, high in-tensities are also previously reported in Germany around $1000 \mathrm{BCE}$, even if with slightly lower values of around $70 \mathrm{~T}$ (Hervé et al. 2017). The high declinations observed at the same period are also in agreement with the directional peak observed in Israel during the LIAA (Shaar et al. 2018). Furthermore, the high intensity shown in the Italian curve around $800 \mathrm{CE}$ could be connected to the well de ned intensity maximum observed in Western Europe (Genevey et al. 2016; Gómez Paccard et al. 2016). Finally, three small intensity peaks observed in the Italian curve between 1000 and 1600 CE seem to agree with those previously observed in France and in Italy (Genevey et al. 2016, 2019). Nevertheless, we should underline that to arrive at clear conclusions about such short and abrupt intensity changes, more data are still required, ideally dated with uncertainties of less than a couple of decades. The collection and investigation of archaeological artefacts with such precise dating is definitely a very difficult and challenging task for the archaeomagnetic community.

\section{Archaeomagnetic dating applications}

Apart from the geomagnetic eld implications, the new curves can be also used as reference curves for archaeomagnetic dating in Italy and nearby countries. Archaeomagnetic dating is a re-liable and promising absolute dating technique, but its precision importantly depends on the availability of a well established reference SV curve for a certain area (Casas and Tema 2019). We report here some examples of archaeomagnetic dating using the new SV curves. The dating was obtained by calculating the probability densities separately for declination, inclination and intensity (when available), after relocating the data to the geographical coordinates of Viterbo. The final dating interval is obtained by combining the separate probability densities (Lanos 2004). In all cases reported below, the archaeomagnetic dating intervals were calculated at a $95 \%$ probability level using the RenDate software.

Castelgoffredo (northern Italy) Tema et al. (2006) presented the directional results of several in situ archaeological structures around Italy. Some of those directions, even if very well defined, 
were not included in the calculation of the preliminary SV curve (Tema et al. 2006) because they lacked precise archaeological dating. Here we used one of these structures to date it with the new reference SV curves. In particular, we dated hearth H1205, excavated at Castelgoffredo
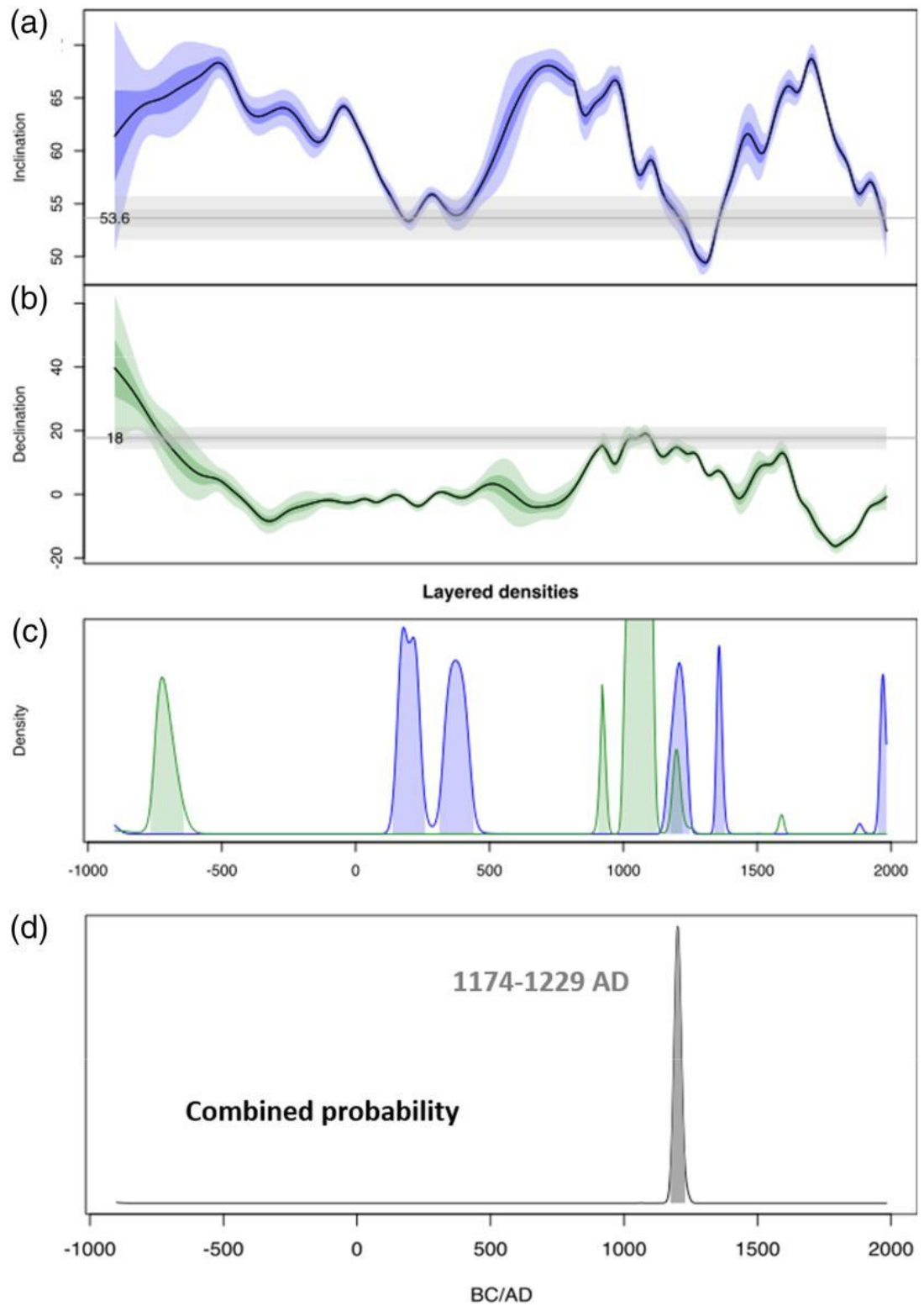

Figure 6 Example of archaeomagnetic dating for the case of Castelgoffredo kiln: (a) inclination plotted over the inclination secular variation (SV) curve; (b) declination plotted over the declination SV curve; (c) probability densities obtained after comparison with the inclination (blue) and declination (green) curves; and (d) date interval calculated at $95 \%$ probability obtained by combining the probability densities of both declination and inclination. 
$\left(45.30^{\circ} \mathrm{N}, 10.45^{\circ} \mathrm{E}\right)$, comparing its direction, $\mathrm{D}=18.0^{\circ}, \mathrm{I}=56.0^{\circ}, \alpha_{95}=2.0^{\circ}, \mathrm{k}=567, \mathrm{~N}=10$, with the new curves (Fig. 6, a, b). The obtained dating interval is very well constrained, indicating that the hearth was used for the last time in 1174-1229 CE, with a 95\% level of probability (Fig. 6, c, d), which is in very good agreement with the medieval age of the construction where it was found (Breda 1986).

Bazzano kiln (northern Italy) Tema and Lanza (2008) investigated the archaeomagnetic direction of a lime kiln situated at Bazzano $\left(44.50^{\circ} \mathrm{N}, 11.08^{\circ} \mathrm{E}\right)$, near Bologna. The archaeomagnetic direction obtained was well de ned with $\mathrm{D}=0.4^{\circ}, \mathrm{I}=60.6^{\circ}, \alpha_{95}=3.1^{\circ}, \mathrm{k}=197$, $\mathrm{N}=12$. At that time, the authors used the preliminary Italian (Tema et al. 2006) and the French (Gallet et al. 2002) SV curves to date the structure obtaining dating intervals of 99 BCE-650 CE (Italian curve) and 268-575 CE (French curve), at 95\% probability level. Here we again dated the same structure using the new directional SV curve, obtaining a date of 438-575 CE. The new dating interval is much shorter than those previously obtained, confirming that the last use of the kiln could have occurred as late as the sixth century CE.

Cumes (southern Italy) Hervé et al. (2016) investigated the full geomagnetic eld vector (declination, inclination and intensity) of two kilns unearthed in the lower city of Cumae $\left(40.85^{\circ} \mathrm{N}\right.$, $14.05^{\circ} \mathrm{E}$ ), near Naples: a tile kiln in the necropolis of the Median Gate (Mausoleum D59) and a pottery kiln at the Cava greca. The mausoleum kiln gave very well defined direction and successful archaeointensity determination obtained with the classical Thellier-Thellier approach (Hervé et al. 2016), $D=357.7^{\circ}, \mathrm{I}=61.9^{\circ}, \alpha_{95}=1.8^{\circ}, \mathrm{k}=358(\mathrm{~N}=18), \mathrm{F}=70.1 \pm 4.4 . \mathrm{T}(\mathrm{N}=13)$, and was therefore used here for comparison with the new Italian curves. As no full vector reference curve for Italy was available at that moment, Hervé et al. dated this structure using the European SCHA.DIF.3k model (Pavón Carrasco et al. 2009). Their results suggested that the Mausoleum kiln was last used between 540 and 646 CE, with a 95\% probability level. Here we again dated the same kiln using the new SV curves for Italy, obtaining a dating of 549-629 CE, with a 95\% probability level. This dating is in very good agreement with that obtained with the SCHA.DIF.3k model: actually, it even improved it, providing a slightly shorter time interval.

Vladeni kiln (Romania) Vladeni Popina Blagodeasca $\left(44.84^{\circ} \mathrm{N}, 27.83^{\circ} \mathrm{E}\right)$ archaeological site is situated in Romania, around $1120 \mathrm{~km}$ from Viterbo. A domestic oven and a kiln were archaeomagnetically studied by Suteu et al. (2008). The kiln, archaeologically dated at $750-$ $1100 \mathrm{CE}$, gave a very well defined magnetic direction of $D=353.5^{\circ}, I=67.1^{\circ}, \alpha_{95}=0.8^{\circ}, k=2340$, $\mathrm{N}=15$. Suteu et al. dated this kiln using the Hungarian reference curve, obtaining a dating interval of 535-880 CE, younger than its presumed archaeological age. Here we again dated this kiln with the new curves obtaining a dating interval of $577-814 \mathrm{CE}$, with a $95 \%$ probability level. This interval is better defined than the previous one, even if the site is located at the limit of the new curves' geographical coverage.

These results con rm the potential of the new curves to offer a reliable dating tool not only for Italy but also for nearby countries where no local reference curves are available. The obtained dating intervals are in good agreement with the archaeological context of the structures studied and seem to offer slightly shorter time intervals with respect to the previous Italian directional SV curve and the European geomagnetic eld model. Undoubtedly, when possible, the use of well constrained local SV curves is favourable for reliable dating, as they can (ideally) reflect local variations in the geomagnetic field, which are particularly important for dating purposes. Of course, when no local curve is available, the use of regional and global geomagnetic eld models as master curves is a valid and precious alternative. However, in these cases, particular attention should be given to the time periods for which sedimentary records are used as reference data for model's calculations (Nilsson et al. 2014). 


\section{CONCLUSIONS}

New directional and intensity SV curves are proposed for the Italian peninsula, calculated from a revised compilation of archaeomagnetic records from both archaeological material and volcanic rocks. The new curves are based on a strict selection of high quality directional and intensity data. The critical evaluation of the available Italian data set showed that one of the most important problems is the reliable dating of the volcanic data and the number of samples used for the archaeointensity determinations. The reliability of the dating not only of the volcanic rocks but also of the reference archaeomagnetic data is in fact an element that is often underestimated, also because in most cases it is difficult to evaluate. The information given in most of the global databases and used for geomagnetic eld modelling does not include elements that can allow the detection of possible unreliable dating, and often this is not always possible even when retrieving the original publications. The evaluation of the Italian records presented here shows that for al-most half the available volcanic data, their traditional historical age is not confirmed. Moreover, in many cases the age attributed to the archaeological structures based on archaeological evidence may be changed as the excavation proceeds and the laboratory analyses of the findings are completed. The laboratory techniques also evolve and improve with time, making necessary the re-evaluation of older data (Kovacheva et al. 2014). It is thus clear that the archaeomagnetic databases should be considered as a continuously evolving tool that should be frequently updated and evaluated, first at local level and then globally.

The new curves presented here offer an estimate of the geomagnetic eld evolution during the last 3000years and can be used for archaeomagnetic dating not only in Italy but also in other nearby countries where no local SV curves are available. Moreover, the first continuous intensity curve for Italy provides new insights into the intensity variations in the central Mediterranean. Even if it is still based on a relatively small number of data, the Italian intensity curve shows periods with high intensities of around $80 \mathrm{~T}$ between 800 and $700 \mathrm{BCE}$ and around $700-800 \mathrm{CE}$. It also shows some other minor peaks around $200 \mathrm{BCE}$ and during the Middle Ages (Fig. 5, c). These high intensity records, even though based on few data, seem to support the high intensities previously identified in the Middle East and Central and Western Europe. Finally, such strong in-tensity SV changes can provide a promising tool for dating displaced pottery fragments since their archaeomagnetic dating is usually problematic due to the lack of directional information. However, it should be underlined that the observed intensity peaks are based on very few reference points and undoubtedly more data from Italy are necessary to con rm them and to better constrain the archaeomagnetic applications based on intensity only records.

\section{ACKNOWLEDGEMENTS}

All the archaeologists who contributed by supporting and promoting archaeomagnetic research in Italy are sincerely acknowledged. Philippe Dufresne is warmly acknowledged for his help with the dating using the RenDate software. The Editor, Cathy Batt, and two anonymous reviewers are sincerely acknowledged for their constructive comments on our manuscript. 


\section{REFERENCES}

Arneitz, P., Leonhardt, R., Schnepp, E., Heilig, B., Mayrhofer, F., Kovacs, P., Hejda, P., Valach, F., Vadasz, G., Hammerl, C., Egli, R., Fabian, K., and Kompein, N., 2017, The HISTMAG database: Combining historical, archaeomagnetic and volcanic data, Geophysical Journal International, 210(3), 1347-59.

Batt, C. M., Brown, M. C., Clelland, S., Korte, M., Linford, P., and Outram, Z., 2017, Advances in archaeomagnetic dat-ing in Britain: New data, new approaches and a new calibration curve, J. Arch. Sci., 85, 66-82.

Böhnel, H., Pavón Carrasco, F. J., Sieron, K., and Mahgoub, A. N., 2016, Palaeomagnetic dating of two recent lava flows from Ceboruco volcano, western Mexico, Geophysical Journal International, 207(2), 1203-15.

Breda, 1986. Castelgoffredo (Mantova) piazza Gonzaga. Edi cio altomedievale. Notiziario Soprintendenza archeologica della Lombardia, 94-6.

Brown, M. C., Donadini, F., Korte, M., Nilsson, A., Korhonen, K., Lodge, A., Lengyel, S. N., and Constable, C. G., 2015, GEOMAGIA50.v3: 1. General structure and modifications to the archeological and volcanic database, Earth, Planets and Space, 67-83.

Calvo, M., Prévot, M., Perrin, M., and Riisager, J., 2002, Investigating the reasons for the failure of palaeointensity experiments: A study on historical lava flows from Mt. Etna (Italy), Geophysical Journal International, 149, 44-63.

Casas, L., and Tema, E., 2019, Investigating the expected archaeomagnetic dating precision in Europe: A temporal and spatial analysis based on the SCHA.DIF.3K geomagnetic eld model, Journal of Archaeological Science, 108, 104972. https://doi.org/10.1016/j.jas.2019.104972

Constable, C., Korte, M., and Panovska, S., 2016, Persistent high paleosecular variation activity in southern hemisphere for at least 10000 years, Earth and Planetary Science Letters, 453, 78-86.

Gallet, Y., Genevey, A., and Courtillot, V., 2003, On the possible occurrence of archaeomagnetic jerks in the geomagnetic eld over the past three millennia, earth planet, Science Letters, 214, $237-42$.

Genevey, A., Gallet, Y., Jesset, S., Thébault, E., Bouillon, J., Lefèvre, A., and Le Goff, M., 2016, New archaeointensity data from French early medieval pottery production $\left(6^{\text {th }}-10^{\text {th }}\right.$ century $\left.A D\right)$. Tracing 1500 years of geomagnetic eld intensity variations in Western Europe. Phys. Earth planet, Int., 257, 205-19.

Genevey, A., Principe, C., Gallet, Y., Clemente, G., Le Goff, M., Fournier, A., and Pallecchi, P., 2019, Re ning the high delity archaeointensity curve for western Europe over the past millennium: Analysis of Tuscan architectural bricks (Italy), Geological Society, London, Special Publications, 497, https://doi.org/10.1144/SP497-2019-74

Gómez Paccard, M., Osete, M. L., Chauvin, A., Pavón Carrasco, F. J., Pérez Asensio, M., Jiménez, P., and Lanos, P., 2016, New constraints on the most significant palaeointensity change in Western Europe over the last two millennia. A non dipolar origin? Earth planet, Science Letters, 454, 55-64.

Hervé, G., Chauvin, A., and Lanos, P., 2013, Geomagnetic eld variations in Western Europe from 1500 BC to $200 \mathrm{AD}$,

Part II: New intensity secular variation curve. Phys. Earth Planet. Int., 218, 51-65.

Hervé, G., Munzi Santoriello, P., Lanos, P., Brune, J. P., Caputo, P., and Regis, C., 2016, Archaeomagnetic dating of two early middle age kilns at Cumae Campania, Italy, ArcheoSciences, Revue d'archéométrie, 40, 35-45.

Hervé, G., et al., 2017, Fast geomagnetic field intensity variations between 1400 and 400 BCE: New archaeointensity data from Germany, Physics of the Earth and Planetary Interiors, 270, 143-56.

Hill, M., and Shaw, J., 1999, Palaeointensity results for historic lavas from Mt Etna using microwave demagnetization/remagnetization in a modified Thellier type experiment, Geophysical Journal International, 139, 583-90.

Incoronato, A., Angelino, A., Romano, R., Ferrante, A., Sauna, R., Vanacore, G., and Vecchione, C., 2002, Retrieving geomagnetic secular variations from lava flows: Evidence from mounts Arso, Etna and Vesuvius (southern Italy), Geophysical Journal International, 149, 724-30.

Jackson, A., Jonkers, A. R. T., and Walker, M. R., 2000, Four centuries of geomagnetic secular variation from historical records, Phil. Trans. R. Soc. Lond. A, 358, 957-90.

Kapper, L., Anesin, D., Donadini, F., Angelucci, D., Cavulli, F., Pedrotti, A., and Hirt, A., 2014, Linking site formation processes to magnetic properties. Rock and archaeomagnetic analysis of the combustion levels at Riparo Gaban (Italy), Journal of Archaeological Science, 41, 836-55.

Kapper, L., Donadini, F., and Hirt, A., 2015, Holocene archeointensities from mid European ceramics, slags, burned sed-iments and cherts, Phys. Earth Planet.Int., 241, 21-36.

Korte, M., and Constable, C., 2018, Archeomagnetic intensity spikes: Global or regional geomagnetic eld features? Frontiers in Earth Science, 6, 17. 
Kovacheva, M., Kostadinova Avramova, M., Jordanova, N., Lanos, P., and Boyadzhiev, Y., 2014, Extended and revised archaeomagnetic database and secular variation curves from Bulgaria for the last eight millennia, Phys. Earth Planet. Int., 236, 79-94. 
Lanos, P., 2004, Bayesian inference of calibration curves, application to archaeomagnetism, in Tools for constructing chronologies, crossing disciplinary boundaries (eds. C. E. Buck and A. R. Millard), 43-82, Lecture Notes in Statistics 177, Springer Verlag, London.

Lanos, Ph., Dufresne, Ph., 2019. ChronoModel version 2.0: Software for chronological modelling of archaeological data using Bayesian statistics. Available from https://chronomodel.com/

Lanos, P., and Philippe, A., 2018, Event date model: A robust Bayesian tool for chronology building,

Communications for Statistical Applications and Methods, 25(2), 131-57.

Lanza, R., and Zanella, E., 2003, Palaeomagnetic secular variation at Vulcano (Aeolian Islands) during the last $135 \mathrm{kyr}$, earth planet, Science Letters, 213, 321-36.

Lanza, R., Meloni, A., and Tema, E., 2005, Historical measurements of the Earth's magnetic eld compared with remanence directions from lava flows in Italy over the last four centuries, Physics of the Earth and Planetary Interiors, 148, 97-107.

Malfatti, J., Principe, C., Arrighi, S., and Arias, C., 2009, L'archeomagnetismo per la datazione delle attività siderurgiche antiche, 213-18, Materiali da costruzione e produzione del ferro. Eds. Cambi, Cabari, Mascione. Edipuglia, In. ISBN:978 8872285626.

Malfatti, J., Principe, C., and Gattiglia, G., 2011, Archaeomagnetic investigation of a metallurgical furnace in

Pisa (Italy), Journal of Cultural Heritage, 12, 1-0.

Molina Cardín, A., et al., 2018, Updated Iberian archaeomagnetic catalogue: New full vector paleosecular variation curve for the last three millennia, Geochemistry, Geophysics, Geosystems, 19, https://doi.org/10.1029/2018GC007781 Nilsson, A., Holme, R., Korte, M., Suttie, N., and Hill, M., 2014,

Reconstructing Holocene geomagnetic eld variation:

New methods, models and implications, Geophysical Journal International, 198(1), 229-48.

Pavón Carrasco, F. J., Osete, M. L., Torta, J. M., and Gaya Piqué, L. R., 2009, A regional archaeomagnetic model for Europe for the last 3000 years, SCHA.DIF.3K: Applications to archaeomagnetic dating, Geochemistry, Geophysics, Geosystems, 10(3), Q03013.

Pavón Carrasco, F. J., Gómez Paccard, M., Hervé, G., Osete, M. L., and Chauvin, A., 2014, Intensity of the geomagnetic eld in Europe for the last 3ka: In uence of data quality on geomagnetic eld modeling, Geochemistry, Geophysics, Geosystems, 15, 2515-30. https://doi.org/10.1002/2014GC005311

Pavón Carrasco, F. J., Tema, E., Osete, M. L., and Lanza, R., 2016, Statistical analysis of palaeomagnetic data during the last four centuries: Evidence of systematic inclination shallowing in lava ow records, Pure and Applied Geophysics, 173(3), 839-48.

Principe, C., Tanguy, J. C., Arrighi, S., Paiotti, A., Le Goff, M., and Zoppi, U., 2004, Chronology of Vesuvius' activity from a.D. 79 to 1631 based on archaeomagnetism of lavas and historical sources, Bulletin of Volcanology, 66, 703-24.

Rolph, T. C., Shaw, J., and Guest, J. E., 1987, Geomagnetic eld variations as a dating tool: Application to Sicilian lavas, Journal of Archaeological Science, 14, 215-25.

Schnepp, E., Thallner, D., Arneitz, P., Mauritsch, H., Scholger, R., Rolf, C., and Leonhardt, R., 2020, New archaeomagnetic secular variation data from Central Europe, I: directions. Geophys. J. Int., 220, 102344.

Shaar, R., Tauxe, L., Ron, H., Ebert, Y., Zuckerman, S., Finkelstein, I., and Agnon, A., 2016, Large geomagnetic eld anomalies revealed in bronze to iron age archeomagnetic data from Tel Megiddo and Tel Hazor, Israel, Earth Plane-tary Science Letters, 442, 173-85.

Shaar, R., Hassul, E., Raphael, K., Ebert, Y., Segal, Y., Eden, I., Vaknin, Y., Marco, S., Nowaczyk, N., Chauvin, A., and Agnon, A., 2018, The tst catalog of archaeomagnetic directions from Isrlael with 4000 years of geomagnetic secular variations, Frontiers in Earth Sciences, 6, 164. https://doi.org/10.3389/feart.2018.00164

Speranza, F., Branca, S., Coltelli, M., D'Ajello Caracciolo, F., and Vigliotti, L., 2006, How accurate is 'paleomagnetic dating'? New evidence from historical lavas from Mount Etna, Journal of Geophysical Research, 111, B12S33.

Suteu, C. A., Batt, C. M., and Zananiri, I., 2008, New developments in archaeomagnetic dating for Romania-a progress report on recent directional studies, Physics and Chemistry of the Earth, 33, 55765.

Tanguy, J. C., Le Goff, M., Principe, C., Arrighi, S., Chillemi, V., Paiotti, A., La Delfa, S., and Patanè, G., 2003, Archaeomagnetic dating of Mediterranean volcanics of the last 2100 years: Validity and limits, Earth and Planetary Science Letters, 211, 111-24. 
Tanguy, J. C., Condomines, M., Le Goff, M., Chillemi, V., La Delfa, S., and Patanè, G., 2007, Mount Etna eruptions of the last 2750 years: Revised chronology and location through archaeomagnetic and ${ }^{226} \mathrm{Ra}$ ${ }^{230} \mathrm{Th}$ dating, Bulletin of Volca-nology, 70, 55-83.

Tema, E., 2011, Archaeomagnetic research in Italy: Recent achievements and future perspectives, in The Earth's magnetic interior (eds. E. Petrovsky, E. Herrero Bervera, T. Harinarayana, and D. Ivers), 213-33, IAGA special Sopron book series, Vol. 1chapter 15, springer. 
Tema, E., and Kondopoulou, D., 2011, Secular variation of the Earth's magnetic eld in the Balkan region during the last eight millennia based on archaeomagnetic data, Geophysical Journal International, 186(2), 603-14.

Tema, E., and Lanza, R., 2008, Archeaomagnetic study of a lime kiln at Bazzano (northern Italy), Physics and Chemistry of the Earth, 33, 534-43.

Tema, E., Hedley, I., and Lanos, P., 2006, Archaeomagnetism in Italy: A compilation of data including new results and a preliminary Italian secular variation curve, Geophysical Journal International, 167, 1160-71.

Tema, E., Morales, J., Goguitchaichvili, A., and Camps, P., 2013a, New archaeointensity data from Italy and geomagnetic eld intensity variation in the Italian peninsula, Geophysical Journal International, 193, 603-14.

Tema, E., Fantino, F., Ferrara, E., Lo Giudice, A., Morales, J., Goguitchaichvili, A., Camps, P., Barello, F., and Gulmini, M., 2013b, Combined archaeomagnetic and thermoluminescence study of a brick kiln excavated at Fontanetto Po (Vercelli, northern Italy), Journal of Archaeological Science, 40, 2025-35.

Tema, E., Fantino, F., Ferrara, E., Allegretti, S., Lo Giudice, A., Re, A., Barello, F., Vella, S., Cirillo, L., and Gulmini, M., 2014, Archaeological, archaeomagnetic and thermoluminescence investigation of a baked clay kiln excavated at Chieri, northern Italy: Contribution to the rescue of our cultural heritage, Annals of Geophysics, 57(5), G0548.

Tema, E., Camps, P., Ferrara, E., and Poidras, T., 2015, Directional results and absolute archaeointensity determination by the classical Thellier and the multispecimen DSC protocols for two kilns excavated at Osterietta, Italy. Stud. Geophys. Geod., 59, 554-77.

Tema, E., Ferrara, E., Camps, P., Conati Barbaro, C., Spatafora, S., Carvallo, C., and Poidras, T., 2016, The Earth's mag-netic eld in Italy during the Neolithic period: New data from the early Neolithic site of Portonovo (Marche, Italy), Earth and Planetary Science Letters, 448, 49-61.

Tema, E., Herrero Bervera, E., and Lanos, P., 2017, Geomagnetic eld secular variation in Paci c Ocean: A Bayesian ref-erence curve based on Holocene Hawaiian lava ows, Earth and Planetary Science Letters, 478, 58-65.

Terra Nova, F., Amit, H., Hartmann, G. A., and Trindade, R., 2016, Using archaeomagnetic eld models to constrain the physics of the core: Robustness and preferred locations of reversed ux patches, Geophysical Journal International, 206, 1890-913. 